\title{
Electronic Information Sources and Services in Anna University Libraries in Tamil Nadu: A Study
}

\author{
S. Thanuskodi
}

Associate Professor, Department of Library and Information Science Alagappa University, 630 003, Karaikudi

\begin{abstract}
The present century is witnessing knowledge revolution resulting from rapid growth in information and communication technology, acceleration of technical change and intensification of globalization. In itially most of the student community has not made use of the invaluable electron ic resources. As time passed the training programmers have greatly removed the hindrances like lack of a wareness, lack of refresher course work etc. It further contributed in motivating the faculty members as the majority student community are relaying upon electronic resources. The Anna University libraries have moved steadily forward in creating new a mb iances for electronic resources which helped their users to find the relevant authentic information that they need regardless of availability at local or global level. Today our cultural heritage is being created by individuals and corporations in digital form as web pages are online publications. The present study concentrated on evaluation of the use of electronic in formation sources and services in terms of use and user satisfaction in Anna University libraries. The analysis shows that 3-4 hours of access to internet is quite common among the respondents of student and faculty members. The Study reveals that the faculty respondents occupy the first position with respect to their overall problems in the use of electronic information sources and services, students the second, non-teaching staff the third and the technical staff last.
\end{abstract}

Keywords World Wide Web (WWW), Internet, CD-ROM, E-Journals, Indest Consortia, Search Engines, OPAC

\section{Introduction}

The $21^{\text {st }}$ century has brought new avenues of opportunities to the library professionals all over the Globe. The doors to libraries are becoming gateways to the global electronic contest through a new constantly changing technology. Innovations are taking place every now and then and bringing challenges to the library users by means of permitting multi-access and multi-users phenomenon to these scholarly communications. There has been a boom in electronic resources across the world in particular the library domain which significantly adds to the wealth of information. Each domain has accumulated all the public information by creating databases in 1960s, 70s, and 80s. Subsequently the IT has taken one more step forward in the creation of gateways, portals and mirror sites which enabled easy access and decongests the information traffic. The new web sites enabled methodologies and embodied systems have been pressed into service to facilitate instant rapid access to the content.

\footnotetext{
* Corresponding author:

thanuskodi_s@yahoo.com (S. Thanuskodi)

Published online at $\mathrm{http} / /$ journal.sapub.org/ library

Copyright (C) 2012 Scientific \& Academic Publishing. All Rights Reserved
}

\section{Changing Scenario in Higher Education}

The higher education scenario is fact shifting its paradigm in using electronic learning resources and research materials from print mode across the world. Effective use of ICT promises to continue to expand its reach and improve its capabilities with amazing proportion of libraries and archives made a typical role in organizing, preserving and providing access to the cultural and historical resources of societies. Digital technologies are used copiously for information production, collection, distribution and storage library especially in the recent times. In today's knowledge based economy the new source wealth is not natural resources or capital or even technology itself. New source of wealth is the skills acquired through education throughout the life. With the advent of World Wide Web information service to the end users is the key target for the professionals. To provide information service, professionals have to go for "State of Art Technology" as mode of communication to collect and manage the available literature.

Innovations in ICT gives publishing industry users and manager of information a new wave to produce, to manage distribute and use of information. So publishing industries comes out with online resources as the solution to subscription to every updated field. Information becomes a 
primary need of the human beings and wealth of information is considered as foremost. Production, management use, dissemination of information etc. are well equipped with the help of Internet. Therefore dissemination of latest and authentic information is speedy way up to the end users is being priority for information managers. Today the world is witnessing different libraries in form of digital achieves, institutional repositories and personal digital libraries, but the major issues which have to be seriously addressed are authenticity of the digitized information and copyright issues to protect the authors or publishers right by using that information, however libraries are in right direction to accommodate the challenges within the form of latest and scholarly information to the user community. New trends like WIFI networks which connect laptop, mobile desktop and even bridge the computer network without physical wire connections are becoming the order of the day.

\section{Electronic Information Resources and Services in Anna University Libraries}

In the year 2005, while inaugurating the national knowledge commission, the Prime Minister of India has emphasized the importance of the library as a key element for the foundation of knowledge. Economy information and knowledge are the pivotal elements in creation of knowledge society. Phenomenal growth of hyper link documents in the network world had created abundant opportunities as well as challenges for library information professionals. The online revolution brought about by World Wide Web accompanied by other advancements in the information and communication technology is having as impressive impact on the publishing industry. The ultimate goal o fany library is to provide quality information services for complete user satisfaction through optimum utilization of the resources in the library. In order to achieve this goal library acquires, preserves and disseminate documentary as well as the non-documentary record of the information. The reader community among 5 Anna University libraries has already accepted the new culture in a big way and is effectively using key journals and online databases on a very large scale. However the e-book culture is yet to pick up the same temp in the Engineering and Technology literature as they exist many standard formats in which many of e-books are available.

\section{Review of Literature}

Tenopir (2003) in his research work titled "Use and Users of Electronic Library Resources: An Overview and Analys is of Recent Research Studies" studied the 200 recent research publications that focus on the use of electronic library resources and were published between 1995 and 2003 in the report for the council on library and information resources. The study used a variety of research methods, including observations, surveys, interviews, experiments and transaction log analysis. The findings show that both faculty and students use and like electronic resources and most readily adopt them if the sources are perceived as convenient, relevant, and time saving to their natural work flow. Print medium is still used for some reading and is part of research in almost every discipline.

Waldman (2003) studied to know what factors encourage students to seek out the information in the library setting in his paper titled "Freshmen's Use of Library Electronic Resources and Self-efficacy" at Breach college library, the City University of New York. The questionnaire was used as tool for collecting data. The findings show that students who visit the library more frequently had higher self efficacy scores than those who reported using the library less often. Students who found the library electronic resources easy to us e had higher self-efficacy scores as compared to those who found the electronic resources difficult to use and students who report being highly motivated to learn about the library's electronic resources have higher self-efficacy scores when compared to those who are motivated to learn.

Yang (2003) conducted a study titled, "Internet Use by Pre-service Teachers in Elementary Education Instruction" which explored the attitude of pre-service elementary educators towards internet use, internet self-efficacy, and internet anxiety and their relationship. The respondents of this survey were all elementary pre-service students enrolled in Core College of Education courses at Idaho State University during 2003. The questionnaires were distributed to 98 students' during regularly scheduled class time and a total of 71 responses were obtained. The implications of the findings suggested that an early and frequent use of the internet across the teacher education curricula was useful in promoting students' internet use and self-efficacy.

Choukhande and Kumar (2004) have studied the information needs and use pattern in their paper titled "Analytical Study of Information Needs and Use Pattern of Faculty Members and Research Scholars of Amravati University". They used a questionnaire method with random sampling technique to collect the data. So me of the findings are: users face difficulty in searching in formation through electronic sources, and they need skill to use the available sources in the library.

Ibrahim (2004) in his study titled "Use and User Perception of Electronic Resources in the United Arab Emirates University (UAEU)" made an attempt to measure the use and perception of the United Arab Emirates University (UAEU) faculty me mbers of electronic resources. He found out that frequency of use of electronic resources was low due to lack of time because of the time needed to focus on teaching; lack of awareness to electronic resources provided by library; ineffective co mmunicat ion channels and language barrier. Stratified random sample questionnaires were sent to the faculty. The questionnaires were self-admin istered. E-mail and phone calls were also made. 25 per cent sample was drawn department-wise. 


\section{Objectives of the Study}

The following objectives are evolved for the purpose of the present study:

- To examine the respondents' duration and quantum of time utilization in search of information.

-To as sess the contemporary use of electronic information resources by the respondents.

-To analyze the respondents' extent of access to e-resources

- To examine the purpose of using of e-resources.

-To study the respondents' satisfaction and problems in utilizing the e-resources

\section{Methodology}

The researcher has employed a well structured questionnaire for collecting the data from the students, faculty members, non-teaching staff and technical staff of the Anna University of Chennai, Coimbatore, Tiruchitappalli, Madurai and Tirunelveli. The questionnaire has been prepared in such a way that the respondents could easily understand the items. A total number of 600 questionnaires were distributed among the respondents. The investigator could collect questionnaires from only 498 out of 600 respondents among whom the questionnaires were distributed. This constitutes $83 \%(498 / 600)$ of the total response.

\section{Data Analysis}

Analys is of data is the ultimate step in research process. It is the link between raw data and significant results leading to conclusions. This process of analysis has to be result oriented.

A study of data in table-1 indicates the category wise distribution of respondents. It could be noted that out of the total 498 respondents, 57.64 per cent of them are students and 22.89 per cent of them are faculty members. In this study, 11.04 per cent of the respondents are non teaching staff and 8.43 percent of them are technical staff. It is concluded that more students followed by faculty members are the respondents in the study.
Table 1. Designation wise Distribution of Respondents

\begin{tabular}{|c|c|c|}
\hline Category & No. of Respondents & Percentage \\
\hline Students & 287 & 57.64 \\
\hline Faculty Members & 114 & 22.89 \\
\hline Non-teaching Staff & 55 & 11.04 \\
\hline Technical Staff & 42 & 8.43 \\
\hline Total & 498 & 100.00 \\
\hline
\end{tabular}

A study of data in table-2 indicates the gender distribution of respondents. It could be noted that out of the total 498 respondents, two thirds of the respondents (62.24\%) belong to the male group and the rest one third of them $(37.76 \%)$ are females. It is concluded that male respondents constitute more in number than female respondents, indicating the presence of male domination in engineering profession in Tamil Nadu.

Table 2. Gender wise Distribution of Respondents

\begin{tabular}{|c|c|c|}
\hline Gender & No. of Respondents & Percentage \\
\hline Male & 310 & 62.24 \\
\hline Female & 188 & 37.76 \\
\hline Total & 498 & 100.00 \\
\hline
\end{tabular}

Data presented in table-3 indicate the respondents' frequency of library $v$ is its. It could be noted that majority of the faculty respondents $(42.98 \%)$ make library visit once in a week. Majority of the non teaching respondents $(36.36 \%)$ make library $v$ isit as and when required. A considerable number of student respondents $(23.34 \%)$ make library visit twice a week and technical staff respondents (26.19\%) make library $v$ isit as and when required. It could be seen clearly from the above discussion that faculty respondents mainly make library visit once in a week and student respondents make high level of library visit at twice a week.

Data presented in table-4 indicate the respondents' frequency of access to internet per day. It could be noted that majority of the student respondents $(40.35 \%)$ have $4-5$ hours of access to internet. Majority of the faculty respondents (36.93\%) have 3-4 hours of access to internet. Around one third of the technical staff respondents (23.81\%) have 4-5 hours of access to internet. Majority of the non teaching respondents $(47.27 \%)$ have above 5 hours of access to internet. It could be seen clearly from the above discussion that 3-4 hours of access to internet is quite common among the respondents of student and faculty members.

Table 3. Respondents' Frequency of Library Visits

\begin{tabular}{|c|c|c|c|c|c|c|c|}
\hline Respondents & Daily & $\begin{array}{c}\text { Thrice a } \\
\text { Week }\end{array}$ & $\begin{array}{r}\text { Twice } \\
\text { a Week }\end{array}$ & $\begin{array}{c}\text { Once in a } \\
\text { Week }\end{array}$ & $\begin{array}{l}\text { Once in a } \\
\text { Fortnight }\end{array}$ & $\begin{array}{c}\text { As and When } \\
\text { Required }\end{array}$ & Total \\
\hline \multirow{2}{*}{ Students } & 26 & 31 & 67 & 67 & 48 & 48 & \multirow{2}{*}{287} \\
\hline & $(9.06)$ & $(10.80)$ & $(23.34)$ & $(23.34)$ & $(16.72)$ & $(16.72)$ & \\
\hline \multirow{2}{*}{ Faculty Members } & 11 & 21 & 14 & 49 & 10 & 9 & \multirow{2}{*}{114} \\
\hline & $(9.65)$ & $(18.42)$ & $(12.28)$ & $(42.98)$ & $(8.77)$ & $(7.89)$ & \\
\hline \multirow{2}{*}{ Non-teaching Staff } & 5 & 6 & 7 & 8 & 9 & 20 & \multirow{2}{*}{55} \\
\hline & $(9.09)$ & $(10.91)$ & $(12.73)$ & $(14.55)$ & $(16.36)$ & $(36.36)$ & \\
\hline \multirow{2}{*}{ Technical Staff } & 7 & 5 & 6 & 6 & 7 & 11 & \multirow{2}{*}{42} \\
\hline & $(16.67)$ & $(11.90)$ & $(14.29)$ & $(14.29)$ & $(16.67)$ & $(26.19)$ & \\
\hline \multirow{2}{*}{ Total } & 49 & 63 & 94 & 130 & 74 & 88 & \multirow{2}{*}{498} \\
\hline & $(9.83)$ & $(12.65)$ & $(18.88)$ & $(26.10)$ & $(14.86)$ & $(17.68)$ & \\
\hline
\end{tabular}


Table 4. Respondents' Frequency of Access to Internet per day

\begin{tabular}{|c|c|c|c|c|c|c|}
\hline Respondents & $\begin{array}{c}\text { Less than } 2 \\
\text { hours }\end{array}$ & 2-3 hours & $3-4$ hours & 4- 5 hours & Above 5 hours & Total \\
\hline Students & $\begin{array}{c}14 \\
(12.28) \\
\end{array}$ & $\begin{array}{c}14 \\
(12.28) \\
\end{array}$ & $\begin{array}{c}22 \\
(19.30) \\
\end{array}$ & $\begin{array}{c}46 \\
(40.35) \\
\end{array}$ & $\begin{array}{c}18 \\
(15.79) \\
\end{array}$ & 287 \\
\hline Faculty Members & $\begin{array}{c}21 \\
(07.32) \\
\end{array}$ & $\begin{array}{c}36 \\
(12.54) \\
\end{array}$ & $\begin{array}{c}106 \\
(36.93) \\
\end{array}$ & $\begin{array}{c}66 \\
(23.00) \\
\end{array}$ & $\begin{array}{c}58 \\
(20.21) \\
\end{array}$ & 114 \\
\hline Non-teaching Staff & $\begin{array}{c}5 \\
(9.09) \\
\end{array}$ & $\begin{array}{c}6 \\
(10.91) \\
\end{array}$ & $\begin{array}{c}7 \\
(12.73) \\
\end{array}$ & $\begin{array}{c}11 \\
(20.00) \\
\end{array}$ & $\begin{array}{c}26 \\
(47.27) \\
\end{array}$ & 55 \\
\hline Technical Staff & $\begin{array}{c}9 \\
(21.43) \\
\end{array}$ & $\begin{array}{c}8 \\
(19.05) \\
\end{array}$ & $\begin{array}{c}6 \\
(14.29) \\
\end{array}$ & $\begin{array}{c}10 \\
(23.81) \\
\end{array}$ & $\begin{array}{c}9 \\
(21.43) \\
\end{array}$ & 42 \\
\hline Total & $\begin{array}{c}49 \\
(9.83) \\
\end{array}$ & $\begin{array}{c}64 \\
(12.85) \\
\end{array}$ & $\begin{array}{c}141 \\
(28.31)\end{array}$ & $\begin{array}{c}133 \\
(26.70) \\
\end{array}$ & $\begin{array}{c}111 \\
(22.28) \\
\end{array}$ & 498 \\
\hline
\end{tabular}

Table 5. Frequency of use of electronic information resources

\begin{tabular}{|c|c|c|c|c|c|}
\hline Resources & Students & $\begin{array}{c}\text { Faculty } \\
\text { members }\end{array}$ & Non-teaching Staff & $\begin{array}{c}\text { Technical } \\
\text { Staff }\end{array}$ & Total \\
\hline CD-ROM & 3.36 & 3.89 & 4.10 & 4.16 & 4.26 \\
\hline CD-Databases & 3.76 & 3.89 & 4.26 & 4.41 & 4.51 \\
\hline Online Databases & 2.14 & 2.56 & 2.89 & 2.99 & 3.85 \\
\hline Online Journals & 2.16 & 2.18 & 2.52 & 3.36 & 3.52 \\
\hline Internet & 3.36 & 3.84 & 3.77 & 4.01 & 3.58 \\
\hline Intranet & 2.26 & 2.84 & 2.96 & 3.39 & 3.96 \\
\hline OPAC & 3.39 & 3.52 & 3.66 & 3.77 & 4.11 \\
\hline Total & 3.77 & 3.96 & 3.99 & 4.26 & 4.33 \\
\hline
\end{tabular}

A study of data in table-5 indicates the designation wise respondents' use of electronic information resources. The technical staff respondents occupy the first position with respect to their overall use of electronic information resources as their secured mean score is 4.26 on a 5 point rating scale. The non-teaching staff respondents take the second position in their overall use of electronic information resources as their secured mean score is 3.99 on a 5 point rating scale. The faculty respondents rank in the third position in their overall satisfaction on use of electronic information resources as their secured mean score is 3.96 on a 5 point rating scale. The student respondents take the fourth position in their overall use of electronic information resources as their secured mean score is 3.77 on a 5 point rating scale. It could be seen clearly from the above discussion that technical staff respondents occupy the first position with respect to their overall use of electronic information resources, non-teaching staff the second, faculty members the third and students the last.

A study of data in table- 6 indicates the designation wise respondents' use of electronic information networks. The student respondents occupy the first position with respect to their overall use of electronic information networks as their secured mean score is 4.10 on a 5 point rating scale. The technical staff respondents take the second position in their overall use of electronic information networks as their secured mean score is 3.96 on a 5 point rating scale. The non-teaching staff respondents rank in the third position in their overall satisfaction on use of electronic information networks as their secured mean score is 3.67 on a 5 point rating scale. The faculty member respondents take the last position in their overall use of electronic information networks as their secured mean score is 3.49 on a 5 point rating scale. It could be seen clearly from the above discussion that the student respondents occupy the first position with respect to their overall use of electronic information networks, technical staff the second, non-teaching staff the third and faculty members the last.

A study of data in table-7 indicates the designation wise respondents' sources of knowledge on use of electronic information resources. The technical staff respondents occupy the first position with respect to their overall sources of knowledge on use of electronic information resources as their secured mean score is 4.10 on a 5 point rating scale. The non-teaching staff respondents take the second position in their overall sources of knowledge on use of electronic information resources as their secured mean score is 3.79 on a 5 point rating scale. The faculty respondents rank in the third position in their overall sources of knowledge on use of electronic information resources as their secured mean score is 3.77 on a 5 point rating scale. The student respondents take the fourth position in their overall sources of knowledge on use of electronic information resources as their secured mean score is 3.76 on a 5 point rating scale. It could be seen clearly from the above discussion that technical staff respondents occupy the first position with respect to their overall sources of knowledge on use of electronic information resources, non-teaching staff the second, faculty members the third and students the last. 
Table 6. Use of Information Networks

\begin{tabular}{|c|c|c|c|c|c|}
\hline Resources & Students & $\begin{array}{c}\text { Faculty } \\
\text { members }\end{array}$ & Non-teaching Staff & $\begin{array}{c}\text { Technical } \\
\text { Staff }\end{array}$ & Total \\
\hline DELNET Services & 4.30 & 4.16 & 4.10 & 3.79 & 3.79 \\
\hline AICTE-INDEST & 4.51 & 4.36 & 4.16 & 3.90 & 3.90 \\
\hline Digital Library & 3.60 & 3.66 & 2.66 & 2.65 & 2.89 \\
\hline $\begin{array}{c}\text { UGC Infonet Services- General } \\
\text { Consortia }\end{array}$ & 3.44 & 3.42 & 2.42 & 2.28 & 2.79 \\
\hline Total & 4.10 & 3.49 & 3.67 & 3.96 & 3.89 \\
\hline
\end{tabular}

Table 7. Sources of knowledge on use of electronic information resources

\begin{tabular}{|c|c|c|c|c|c|}
\hline Resources & Students & $\begin{array}{c}\text { Faculty } \\
\text { members }\end{array}$ & Non-teaching Staff & $\begin{array}{c}\text { Technical } \\
\text { Staff }\end{array}$ & Total \\
\hline Self leaning & 3.79 & 3.89 & 4.10 & 4.22 & 4.36 \\
\hline Colleagues or friends & 2.79 & 2.52 & 3.36 & 3.79 & 3.89 \\
\hline Formal courses & 3.37 & 3.87 & 4.10 & 4.26 & 4.36 \\
\hline Library training & 2.52 & 2.42 & 2.56 & 3.79 & 3.82 \\
\hline Total & 3.76 & 3.77 & 3.79 & 4.10 & 4.12 \\
\hline
\end{tabular}

Table 8. Satisfaction on familiar search engines

\begin{tabular}{|c|c|c|c|c|c|}
\hline Search Engines & Students & $\begin{array}{c}\text { Faculty } \\
\text { members }\end{array}$ & Non-teaching Staff & $\begin{array}{c}\text { Technical } \\
\text { Staff }\end{array}$ & Total \\
\hline Google & 2.52 & 2.42 & 2.56 & 3.79 & 3.82 \\
\hline Lycos & 3.76 & 3.77 & 3.79 & 4.10 & 4.12 \\
\hline Yahoo & 2.11 & 2.21 & 2.36 & 2.86 & 3.39 \\
\hline Alta vista & 3.37 & 3.56 & 3.89 & 4.11 & 4.26 \\
\hline In fo seek & 2.14 & 2.16 & 2.56 & 2.76 & 3.36 \\
\hline BUBL & 3.52 & 3.76 & 3.99 & 4.01 & 4.11 \\
\hline Total & 4.10 & 4.16 & 3.89 & 3.79 & 3.76 \\
\hline
\end{tabular}

Table 9. Respondents' with Purpose of Using E-resources

\begin{tabular}{|c|c|c|c|c|c|}
\hline Purpose & Students & Faculty members & Non-teaching Staff & Technical Staff & Total \\
\hline For research & 3.77 & 4.21 & 3.88 & 3.96 & 4.11 \\
\hline $\begin{array}{c}\text { For improvingarea of } \\
\text { specialisation }\end{array}$ & 2.79 & 3.11 & 2.56 & 2.76 & 3.56 \\
\hline E-books & 3.39 & 3.79 & 2.41 & 2.51 & 3.52 \\
\hline Career Information & 2.96 & 3.79 & 4.01 & 3.77 & 4.11 \\
\hline E-journals & 2.79 & 3.39 & 2.15 & 2.16 & 3.30 \\
\hline General Information & 4.11 & 4.16 & 3.81 & 3.89 & 4.26 \\
\hline Sending and receiving e-mail & 3.96 & 4.10 & 3.72 & 3.59 & 4.15 \\
\hline Entertainment & 3.96 & 3.99 & 3.52 & 3.66 & 4.11 \\
\hline Total & 4.21 & 4.31 & 3.99 & 4.01 & 4.39 \\
\hline
\end{tabular}

A study of data in table- 8 indicates the designation wise respondents' satisfaction on familiar search engines. The faculty respondents occupy the first position with respect to their overall satisfaction on familiar search engines as their secured mean score is 4.16 on a 5 point rating scale. The student respondents take the second position in their overall satis faction on familiar search engines as their secured mean score is 4.10 on a 5 point rating scale. The non-teaching staff respondents rank in the third position in their overall satisfaction on familiar search engines as their secured mean score is 3.89 on a 5 point rating scale. The technical staff respondents take the last position in their overall satis faction on familiar search engines as their secured mean score is 3.79 on a 5 point rating scale. It could be seen clearly from the above discussion that the faculty respondents occupy the first position with respect to their overall satisfaction on familiar search engines, students the second, non-teaching staff the third and the technical staff last.
A study of data in table-9 indicates the designation wise respondents' purpose of using e-resources. The faculty respondents occupy the first position with respect to their overall purpose of using e-resources as their secured mean score is 4.31 on a 5 point rating scale. The student respondents take the second position in their overall purpose of using e-resources as their secured mean score is 4.21 on a 5 point rating scale. The technical staff respondents take the third position in their overall purpose of using e-resources as their secured mean score is 4.01 on a 5 point rating scale. The non-teaching staff respondents rank in the last position in their overall purpose of using e-resources as their secured mean score is 3.99 on a 5 point rating scale. It could be seen clearly from the above discussion that the faculty respondents occupy the first position with respect to their purpose of using e-resources, students the second, the technical staff third and non-teaching staff the last. 
Table 10. Problems in the use of electronic information sources and services

\begin{tabular}{|c|c|c|c|c|c|}
\hline Problems & Students & Faculty members & Non-teaching Staff & $\begin{array}{c}\text { Technical } \\
\text { Staff }\end{array}$ & Total \\
\hline Lack of knowledge on terminology & 3.52 & 3.02 & 3.89 & 4.22 & 4.21 \\
\hline $\begin{array}{c}\text { Limite d number of computer } \\
\text { machines }\end{array}$ & 3.60 & 3.12 & 4.10 & 4.26 & 4.12 \\
\hline In formation is not updated & 3.69 & 2.59 & 3.88 & 3.90 & 4.11 \\
\hline Do not un der stand the process & 2.26 & 2.49 & 2.89 & 3.76 & 3.96 \\
\hline Not aware of the services available & 2.12 & 2.44 & 3.56 & 2.65 & 3.11 \\
\hline System is not user friendly & 2.44 & 3.89 & 2.89 & 3.16 & 2.77 \\
\hline Access to limited information & 3.90 & 3.76 & 3.77 & 2.56 & 2.26 \\
\hline Total & 4.01 & 4.22 & 3.81 & 3.77 & 2.89 \\
\hline
\end{tabular}

Table 11. Respondents' Views on Library Services

\begin{tabular}{|c|c|c|c|c|c|c|}
\hline Respondents & Excellent & Good & No Opinion & Poor & Very Poor & Total \\
\hline \multirow{2}{*}{ Students } & 65 & 92 & 10 & 44 & 76 & \multirow{2}{*}{287} \\
\hline & $(22.65)$ & $(32.06)$ & $(3.48)$ & $(15.33)$ & $(26.48)$ & \\
\hline \multirow{2}{*}{ Faculty Members } & 19 & 42 & 5 & 24 & 24 & \multirow{2}{*}{114} \\
\hline & $(16.67)$ & $(36.84)$ & $(4.39)$ & $(21.05)$ & $(21.05)$ & \\
\hline \multirow{2}{*}{ Non-teaching Staff } & 4 & 7 & 20 & 17 & 7 & \multirow{2}{*}{55} \\
\hline & $(7.27)$ & $(12.73)$ & $(36.36)$ & $(30.91)$ & (12.73) & \\
\hline \multirow{2}{*}{ Technical Staff } & 7 & 9 & 8 & 8 & 10 & \multirow{2}{*}{42} \\
\hline & $(16.67)$ & $(21.43)$ & $(19.05)$ & $(19.05)$ & $(23.81)$ & \\
\hline Total & $\begin{array}{c}95 \\
(19.07)\end{array}$ & $\begin{array}{c}150 \\
(30.12)\end{array}$ & $\begin{array}{c}43 \\
(8.63)\end{array}$ & $\begin{array}{c}93 \\
(18.68)\end{array}$ & $\begin{array}{c}117 \\
(23.49)\end{array}$ & 498 \\
\hline
\end{tabular}

A study of data in table- 10 indicates the designation wise respondents' problems in the use of electronic information sources and services. The faculty respondents occupy the first position with respect to their overall problems in the use of electronic information sources and services as their secured mean score is 4.22 on a 5 point rating scale. The student respondents take the second position in their overall problems in the use of electronic information sources and services as their secured mean score is 4.01 on a 5 point rating scale. The non-teaching staff respondents rank in the third position in their overall problems in the use of electronic information sources and services as their secured mean score is 3.81 on a 5 point rating scale. The technical staff respondents take the last position in their overall problems in the use of electronic information sources and services as their secured mean score is 3.77 on a 5 point rating scale. It could be seen clearly from the above discussion that the faculty respondents occupy the first position with respect to their overall problems in the use of electronic information sources and services, students the second, non-teaching staff the third and the technical staff last.

Table-11 presents data on the respondents' views on lib rary services. It could be noted that one third of the student respondents $(32.06 \%)$ and faculty respondents $(36.84 \%)$ observe that library services are good. The non teaching staff respondents $(36.36 \%$ ) view main ly that they have no opinion about library services. A considerable number of technical staff respondents $(21.43 \%)$ perceive about the good performance of library service. It is concluded that student and faculty respondents view mainly about the good performance of Anna University lib rary services.

\section{Recommendations}

-More and more significant efforts are required to increase the awareness of new technologies among the library staff of Anna University. This can be achieved by deputing them to larger network operations abroad like OCLC USA, net-library USA, IEEE-USA, JANET UK, Lenin library consortia in Moscow. These programes can either short time or long time which will sharpen the skills of the staff and indirectly give benefit to the system.

- There is also an urgent need to conduct orientation programs for the faculty researchers and students for familiarizing with the networks, electronic resources, portals, gateways, open sources etc., which they use in day to day academic and research works.

-All the 5 Anna University libraries be connected through a powerful network which have the scalable architecture to upgraded at a later dates. This will ensure uniformity in the services and familiarity with the operations besides fact access to the resources available in all the center.

- The libraries must cooperate among themselves in sharing the responsibilities by way of creating authority files, list groups, bulletin boards, alerts etc., periodically to update the clients.

\section{Conclusions}


The library environment has currently undergone drastic change in terms of collections and services. The prolife ration of e-resources has had a significant impact on the way the academic commun ity uses, stores, and preserves information. The advantages of e-resources have drawn attention of the library users to a great extent. Accordingly, these resources have occupied a significant place in the collection and budget of almost all libraries. Faculty members and students attitudes seem to be very positive towards e-resources for their study and research and the role of libraries as gateway to provide assistance in accessing these resources. The study reveals that the students and faculty members of Anna University, are using the available e-resources satisfactorily. At the same time the Central Libraries of Anna University is playing an important role in promotion, assistance and guidance in accessing the e-resources. Still there is enough scope for Central Library to develop its infrastructural facilities for accessing e-resources, procurement of more e-resources as per requirement, motivating users for assessing open source e-resources.

\section{REFERENCES}

[1] Choukhande, Vaishali G.; and Kumar P.S.G. (2004), "Analytical Study of Information Needs and Use Pattern of
Faculty Members and Research Scholars of Amravati University," ILA Bulletin, 40 (3), pp.23-31.

[2] Gibaldi, Joseph (2004), “MLA Handbook for Writers of Research Papers." 6th edition Affiliated East- West Press, New Delhi, pp.1-361.

[3] Johnston, Chris. (2003), Call to put research free on websites. Times Higher Education Supplement, December 19, p.7

[4] Ibrahim, Ahmed Elhafiz. (2004), "Use and User Perception of Electronic Resources in the United Arab Emirates University (UAEU)," Libri, 54, pp.18-29.

[5] Monopoli, Mari.; Nicholas, David.; Georgiou, Panagiotis.; and Karfiati, Marima. (2002), "A User-oriented Libraries: Case Study 'The Electronic journals' Service of the Library Information Service of University of Patras, Greece." Aslib Proceeding, 54(2), pp.103-107.

[6] Waldman, Micacla. (2003), "Freshmen's Use of Library Electronic Resources and Selfefficacy," Information Research, 8(2), Jan.

[7] Woodward, H.; and McKnight, C. (1995), "Electronic Journals Issues of Access and Bibliographical Control." Serials Review, 21 (2), pp. 71-78.

[8] Yang, Shi-Wen. (2003), "Internet Use by Pre-Service Teachers in Elementary Education Instruction," Dissertation, Idaho State University, DAI-A 64/06 (2003):189.7, July 2004 http://www.ub.uni.com/disertations/fullcit/3094895 accessed on $21 / 12 / 2010$ 